\title{
Guicciardini and Economic (In)equality
}

\author{
Nikola Regent
}

\begin{abstract}
The article examines several aspects of economic (in)equality in the writings of Francesco Guicciardini. In light of a recent erroneous portrayal of Guicciardini as an advocate of wealthy oligarchs, the article emphasises Guicciardini's appreciation of the Spartan model of economic equality - even if it is unfeasible in the prevailing Florentine circumstances. Guicciardini, seeking to turn the polity towards the pursuit of virtue, argued for measures which would diminish the esteem for wealth in Florence. Nevertheless, Guicciardini was against heavy taxation of the richer citizens: the argument of the "equality of sacrifice" in taxation (which Guicciardini himself first formulated in writing), and the nuanced answer on this point, which he offers to the proponents of progressive taxation, are examined. The article seeks to explain the prima facie contradiction between Guicciardini's reverence for the Spartan system and his 'proto-libertarian' defence of accumulated property, and the rights of the better-off citizens against expropriation. In both cases, it is argued, Guicciardini's position is determined by his concern for virtue and the conditions favourable to its pursuit. The article stresses complexity of Guicciardini's views.
\end{abstract}

KEYWORDS: Francesco Guicciardini; economic equality; economic inequality; "equality of sacrifice" in taxation; corruptive effects of wealth; virtue

JEL CODES: B11; B31; H10; H20; P40; P41

For a sixteenth-century political thinker (and historian), Francesco Guicciardini ${ }^{1}$ demonstrates a remarkable level of interest in economic issues. Unlike his more famous older friend and co-citizen Machiavelli, the younger Florentine paid close attention to topics connected with economy, trade and finance, both public and private. Still below thirty, the young Florentine ottimato Guicciardini is already sent to a very important diplomatic mission to Spain in 1512. He uses his ambassadorship (1512-13) to sharply observe his host country: his Relazione di Spagna, written in this period, describes not just the country's politics and the mores of its inhabitants - we find perceptive observations about the country's economy, trade and (a lack of) industriousness in its population (Guicciardini 1864, 273-274, 275-277). Guicciardini's correspondence from this period also shows his lively interest in Portuguese trade with the East Indies, and the consequences of the Spanish gold influx from the West

CONTACT: Nikola Regent Email: nikola.regent@anu.edu.au School of Politics and International Relations, Australian National University, Canberra, ACT 2601, Australia.

I thank the referees for their comments.

${ }^{1}$ All translations from Guicciardini are my own. The original text is provided in the footnotes for the quotations and, occasionally, characteristic passages: a number of works are untranslated and/or difficult to obtain (even in the original), and this is, moreover, a standard practice in recent English-language scholarship. 
Indies: a keen observer, he noticed the importance of these developments already in $1513 .^{2}$ Such interests persisted till his last years: thus his celebrated history, Storia d'Italia, discusses Portuguese commerce with the Orient, and connections and effects it made on the Venetian trade, as the Serenissima previously had a monopoly in transporting the sought-after oriental goods to Europe (1929, VI.9). Similarly, Guicciardini's detailed notes, published as a part of his Ricordanze, show how much attention he dedicated to his personal finances. ${ }^{3}$

The most prominent of Guicciardini's writings on economic issues is undoubtedly his La Decima scalata, the first treatise ever written on progressive taxation. In a recent article I offered a detailed analysis of its arguments, given both for and against the proposed progressive tax in Florence by the two of the treatise's speakers (Regent 2014). This article, in contrast, seeks to offer a more general account of Guicciardini's writings on, and various discussions of, economic (in)equality. For, apart from La Decima scalata, Guicciardini's other works, particularly those focused on organising and reforming the Florentine government, show an interest in economic equality (or inequality), and its influences on the polity and its citizens. The article seeks to explore the economic aspects of Guicciardini's political thought in more details, building upon my previous work. A decade ago, I discovered the importance of the Lacedaemonian example and Lycurgus' constitution in Guicciardini's early political writings (Regent 2008); in the same article I simultaneously

\footnotetext{
${ }^{2}$ Guicciardini compares the trade between Lisbon and Malacca, and Lisbon and Calicut, in his letter to his brother Luigi, Valladolid, 17 June 1513 (Guicciardini 1986, 453-456; cf. also Guicciardini's letter to the same on 27 June, 464-465). Guicciardini goes into such minutiae to provide a detailed list of all the goods and their quantities, for a ship recently arrived from Malacca (455) and for a ship from Calicut (456). In the same letter he also discusses Spanish discoveries in the West Indies and the quantities of gold they are getting from there - a fifth of which goes to the Spanish king and enormously increases his power (454-455).

${ }^{3}$ See Guicciardini 1991 or another edition of Ricordanze. Ridolfi 1967 clearly shows how much attention Guicciardini gave to his remuneration in negotiating his various commissions and offices, when he worked for the Medici popes. See also Nuccio 1984, 906-912, on Guicciardini's concerns about practical fiscal issues and policies during his governorships for the Medici popes.
} 
uncovered the crucial influence of Plutarch, whose Vitae were Guicciardini's key reading responsible for his appreciation of Sparta. ${ }^{4}$

The plan of this article is as follows. Section 1 will re-examine Guicciardini's interest in Sparta, his thoughts about the Lacedaemonion model of economic equality - and its applicability in modern Florentine circumstances. Section 2 will focus on the issue of taxing the rich and the idea of equality of sacrifice (or, in Guicciardini's words, discomfort) in taxation, and how he answers to that argument offered by the proponents of progressive tax. Section 3 will seek to resolve and explain the prima facie contradiction between Guicciardini's reverence for the Spartan system and his defence of accumulated property, and the rights of the better-off citizens against expropriation. Finally, section 4 will provide concluding remarks, emphasising complexity of Guicciardini's views and the significance of reached insights both as a correction of recent distorted portrayal of his ideas, and for understanding the ideal of (economic) equality in the history of economic and political thought.

\section{Guicciardini and Sparta: a re-examination}

A recent piece on "the problem of plutocracy" mentions how "a long tradition of republicans... proposed a variety of institutional measures for formally bestowing on the wealthy disproportionately greater political voice and opportunity, both as a necessary means of protecting property rights and on the assumption that the wealthy, due to their economic stake in society, would have a superior incentive to (re)cognize and pursue the genuine public interest". The author includes Guicciardini as one of five examples of such republican thinkers (Green 2016a, 88; 2016b, 52). He does not provide any source, either Guicciardini or

\footnotetext{
${ }^{4}$ Regent 2008 showed Pocock's mistake: Pocock argued earlier $(1975,135)$ that Savonarola was the key inspiration for the early Guicciardini's argument against luxury.
} 
secondary literature ${ }^{5}$ nevertheless, it is obvious that the statement was inspired by author's reading of a recent book on Machiavelli the "democrat" - where Guicciardini is portrayed as a chief advocate of a republican regime where a clique of a few wealthy (or wealthiest) citizens rule (McCormick 2011). ${ }^{6}$

Such a misrepresentation of Guicciardini's views reinforces the need ${ }^{7}$ to re-examine the case about Guicciardini and Sparta, with an emphasis on the question of economic equality, and the need of giving lesser esteem to wealth. Discorso di Logrogno, Guicciardini's first known political treatise, was finished on 27 August 1512 during Guicciardini's Spanish ambassadorship. The treatise, whose other, lesser-used title, is Del modo di ordinare [or mantenere] il governo popolare, lays out a detailed plan of a carefully balanced constitution to order a "popular government" (i.e. a republic) in Florence (Guicciardini 1932c). ${ }^{8}$ However, what really interests us here, is the very end of the treatise; as Nelson $(2004,70)$ put it, "[a]t the end of his essay [Guicciardini] includes a remarkable coda". For, as Guicciardini writes, the detailed plan which he proposed in the bulk of the treatise, which is feasible and appropriate to Florentine conditions, achieves relatively limited results: "All these things would make if not a perfect institution of republic, at least [one] more than mediocre" $(1932 c, 257){ }^{9}$

\footnotetext{
${ }^{5}$ Unlike two other examples, Aristotle and Montesquieu, both themselves quoted later on the same page.

${ }^{6}$ Green, indeed, previously commented extensively on McCormick 2011: see Green 2011, esp. 186, where Guicciardini is mentioned as one of three thinkers exemplifying (according to McCormick) "the inherently oligarchic features of the republican tradition itself'.

${ }^{7}$ As Guicciardini's political and economic thought is hardly known in the Anglophone world, McCormick's account can easily mislead unsuspecting authors, as was the case with Green. For criticism of McCormick, see infra, nn. 23, 67 and 69.

${ }^{8}$ While all the references will be to Guicciardini 1932c, Palmarocchi's critical edition, occasional differences with the first edition, Guicciardini 1858, will be pointed out. The date of completion is noted at the end of the treatise (1932c, 259). It is ironic that the republic which Guicciardini wanted to reorder fell within next few days, due to Spanish army: the infamous sack of Prato started on 29 August, Soderini's government fell on 31 August (he went into exile), first of the Medici entered Florence on 1 September. Yet, the Florentine ambassador was apparently left in dark about the incoming events; King Ferdinand excelled at dissimulation. For a later account of these events in Storia d'Italia, see Guicciardini 1929, XI.4; cf. Palmarocchi 1939. (Discorso di Logrogno must be the earliest treatise written by Guicciardini: in the manuscript, which I was able to locate and examine in l'archivio Guicciardini in Florence, two other shorter treatises immediately follow.)

9 "Tutte queste cose farebbono se non una perfetta instituzione di republica, almeno più che mediocre."
} 
To do better than that, and to lead the republic to a higher level, requires far more radical solutions. To do so, one has to "reach the root of delicacies and softness of our souls, which make men effeminate and give cause to infinite evils" (257).$^{10}$ And at the root of all problems is wealth, and "the immoderate appetite" for it: it has an extremely pernicious effect on the minds of men, and their desires; it redirects them from the pursuit of virtue to the pursuit of material aims. Instead of desiring real glory which virtue provides, they are vying for riches: numerous dishonesties and offences are committed on this road (257). ${ }^{11}$ This is classical corruption, detested already by the ancient authors: these "universal disorders" are characteristic both of Florence and of wider world, and "little else is left but an ardour to enrich [oneself] or to use riches for evil purposes" (257). ${ }^{12}$

Guicciardini's early political writings are characterised by medical metaphors. The corruption caused by excessive wealth is thus described as a disease, and possible solutions described in medical terms (see Regent 2008). "There are perhaps some remedies to be able to moderate a bit these evils, but not that many to make a notable effect in a disease so universal, so old and deep-seated in the minds of men." (Guicciardini 1932c, 257). ${ }^{13}$ What is in fact needed, to achieve success, is a radical operation to remove the disease:

It would be required to be cut out with a knife of Lycurgus, who in one day extirpated from Lacedaemon all the riches and sumptuousness, accummulating together possessions of everybody, dividing them then in equal parts, forbidding the money, removing all the uses for which riches are desired, of sumptousness, of banquets, of abundance of servants, of beauties of cloths and furnishing. Surely an awesome thing, to what self-restraint, and to what ardour for virtue and low esteem for goods he lead in one day his city, and with how many beautiful and glorious practices he endowed it... in a way that the orders and the laws it had lasted many hundreds of years... while it

\footnotetext{
10 “...perchè a volerla condurre in maggiore grado bisognerebbe venire alla radice delle delicatezze e mollizie delli animi nostri, che fanno li omini effemminati e danno causa a infiniti mali”.

11 “...la tanta riputazione in che sono le ricchezze, lo appetito immoderato delle quali leva il desiderio della vera gloria aliena li animi dal cercare le virtù e li introduce in mille usurpazioni e in mille disonestà."

12“Sono questi disordini molto universali in ognuno, molto abituati, nè solo sparsi per la città nostra ma per tutto el mondo, dove non è rimasto se non uno ardore di arricchire o di usare le ricchezze in mali usi e delicatamente. Nè incomincia questa corruttela oggi nel mondo... di che fanno fede li scrittori antichi che tanto detestano ed esclamano contro a' vizi delle età loro."

13 "Rimedi ci sono forse qualcuni per potere un poco moderare questi mali, ma non già tanti che e' faccino effetto notabile in una malattia sì universale, sì vecchia e tanto radicata nei menti delli uomini." (Note the difference with Guicciardini 1858, 312: "Remedii ci sono forti e qualcuni.")
} 
had lived under those, it was many times by potency and force the head of Greece, but always by glory and opinion of virtue with the foreign nations the first. $(257-258)^{14}$

My previous work on Guicciardini (Regent 2008) established beyond doubt that the origin and inspiration for his argument are Plutarch and his lives of the Spartan reformers; ${ }^{15}$ even the key expression, "the knife of Lycurgus", originates from Plutarch. What I am interested in this article, are the economic aspects of the question - and the (un)feasibility of introducing a Lycurgianesque reform in Florence. In the Discorso di Logrogno, Guicciardini makes it clear how realistic would be the attempt to emulate Lycurgus and try to introduce such a "perfect republic": "For us it has only remained to marvel and exclaim about such a great thing, but to reduce it in one act is not licit either to hope or even less to want... this disease is so difficult that it is impossible to extirpate it" (1932c, 258). ${ }^{16}$ Removal of the disease requires a prior removal of the "uses" for which riches are desired: because of weak character which men have in modern times, this cannot be done (258). ${ }^{17}$

However, the decisive reason against a radical reform is not in the weakness of human nature. It is in actual foreign political circumstances, which are too dangerous to allow such a forceful operation on the Florentine patient. Guicciardini's often-forgotten treatise on progressive taxation, La Decima scalata, provides here a crucial answer. The problem is that the Florentine republic is unarmed (for more details, see discussion in Regent 2008, 7-8). And without armi proprie one can hardly commit the polity to such a difficult experiment:

\footnotetext{
14 "Bisognerebbe a tagliarla el coltello di Licurgo, el quale estirpò in uno dì da Lacedemone tutte le ricchezze e suntuosità, accumulando insieme le facultà di tutti, dividendole di poi per equali part, vietando e' danari, levando tutti li usi perchè le ricchezze si desiderano, di suntuosità, di conviti, di copia di servi, di bellezze di veste e masserizie. Cosa certo mirabile, in quanta continenza, e in quanto ardore di virtù e poca estimazione della roba conducessi in un giorno la città sua, e di quanti belli e gloriosi esercizi la empiessi... in modo che li ordini e le leggi sue durassino molte centinaia di anni... mentre visse sotto quelle, fu molte volte di potenzia e forze capo della Grecia, ma sempremai di gloria ed opinione di virtù apresso alle nazione forestiere la prima."

15 For an examination of the Lacedaemonian influence on treatment of luxury in early-modern republican thought, see Regent 2019. I analyse the importance of Plutarch's role, and the influence of the Platonic account (inspired by Sparta). The article offers a useful comparison of Guicciardini and Montesquieu and (especially) Mably; it also uncovers Montesquieu's almost unknown work, Dialogue de Xantippe, showing the importance of Lacedaemon for his idea of republic.

16 "A noi è rimasto el poterci maravigliare ed esclamare di cosa tanto notabile, ma di ridurla in atto non ci è lecito non che sperarlo a pena desiderarlo... questa malattia è tanto difficile che gli è impossibile estirparla."

17 “....bisognerebbe, come fece lui [Licurgo], levare li usi per e' quali le ricchezze si desiderano, e questo per la mollizie delli uomini non si può non che altro disegnare."
} 
the dangerous external environment does not allow it. Guicciardini's mouthpiece in the treatise makes it clear that "in our times it would be impossible to reduce men to a similar community [vivere]". To imitate the Spartan example, one would need to abolish "not only possessions, but also money, merchandise, foreign commerce and every humanity". And, yet, this is not enough: "it does not stop with possessions only, because if this example is to be valid, it is necessary to follow it in full or not even mention it" (Guicciardini 1867a, 375). ${ }^{18}$ This means "having arms in hand" as the Lacedaemonians did; in contrast, the Florentines, "not given to arms", have no other way to defend their dominion and liberty but with riches, which are crucial for providing foreign soldiers and other necessary provisions $(375){ }^{19}$

This argument from La Decima scalata helps us to comprehend better more moderate suggestions which Guicciardini put forward at the very end of the Discorso di Logrogno. "I well believe that giving the city to arms, and having the way open to become glorious with them, distributing the magistrates with regard to good fame and bearing of men, making easy the punishment of the crimes of those who err, that all these things together will make the rich to be in less esteem than today" $(1932 \mathrm{c}, 258) .{ }^{20}$ Like in Lacedaemon, the virtuous behaviour should decide men's standing in the city, not their wealth. More particular measures, to limit sumptuousness and outer expression of wealth, are recommended, as is the limitation of dowries. His goal is, Guicciardini makes it very clear, "an institution of republic

\footnotetext{
18 ' $\mathrm{E}$ a' tempi nostri sarebbe impossibile ridurre gl' uomini a uno vivere simile, il quale chi vuole imitare bisogna che levi via non solo le possessioni, ma i denari, le mercanzie, i commerci de' forestieri e ogni umanità; e non provvegga nelle possessioni sole, perchè volendo valersi di quello esempio, è neccesario seguitarlo in tutto o non ne fare menzione..." (Palmarocchi's edition, Guicciardini 1932b, 214, has mercatantie.)

19 “...chi volesse tenere quella via, bisognerebbe avere le armi in mano come loro [Lacedemoni]... poichè voi non siete dati alle armi... come potete voi difendere lo Stato vostro se non con le ricchezze con le quali conducete i soldati forestieri e fate le altre provvisioni che bisognano a difendere questo dominio e la vostra libertà?"

20 "Credo bene che dandosi la città alle arme, ed essendo aperta la via di diventare glorioso con quelle, distribuendosi e' magistrati con riguardo della buona fama e portamenti delli uomini, sendo facile el punire e' delitti di chi errassi, che tutte queste cose insieme farieno e' ricchi essere in meno esistimazione che non sono oggi."
} 
where it is designed to remove inducement to riches" $(258-259) .{ }^{21}$ Wealth should not be required to be able rise to prominence in the city; thus the limitation of dowries is described as "a great benefit to men virtuous and poor" (259). ${ }^{22}$

It is perfectly obvious that Guicciardini wants to advance virtue, and that he is not the advocate of wealthy "oligarchs": McCormick's presentation of the Discorso di Logrogno puts things on their head. ${ }^{23}$ The early Guicciardini is fully committed to the advancement of a system where the harmful effects of wealth and greediness are eradicated, and where personal virtue is cherished: a citizen's status should be the result of his own merit, and not of the social position and prominence of his ancestors. ${ }^{24}$ The strength of Guicciardini's commitment is confirmed in the last sentence: he finishes the treatise with a hope that God "will one day want to reduce that republic in this or some similar way of good institution and good government, which to see and for which to exist in our times, I would without any reserve lay my possessions and my life" (259). ${ }^{25}$

\footnotetext{
21 “...con una instituzione di republica dove si disegni tôrre fomento alle ricchezze."

22 "...perchè si farebbe uno grande beneficio alli uomini virtuosi e poveri."

${ }^{23}$ McCormick claims that Guicciardini's blueprint is stacked in favour of "the most wealthy individuals" and that the most "virtuous, prudent, just" should be read the most "wealthy and prominent" (cf. McCormick 2011, 108 and 110, quoted in n. 69 infra). This is exactly the reverse from Guicciardini's explicit statement on citizen's personal merit (quoted in the next footnote). It is hard to pretend that the statement does not exist: McCormick actually quotes thrice from the very next page in the Moulakis' translation (Guicciardini 1998, 144, quoted in McCormick 2011, 123 (all three times); the mentioned statement is at 142-143 in Moulakis). McCormick may have been unaware of (or perhaps has chosen to disregard) my analysis in Regent 2008; however, he was clearly aware of Nelson 2004 and "an ancient 'Greek republican' sympathy for economic equality" (McCormick 2011, n. 26 at 191), with Nelson very unambiguously describing Guicciardini sympathetic to such views. Indeed, in n. 39 at 203 and n. 6 at 208 McCormick again quotes Nelson 2004; both loci explicitly refer to ch. 2 - where Nelson also discusses Discorso di Logrogno (70-73), and makes a firm argument for "Guicciardini's deep internalization of key aspects of the Greek story" (71), i.e. what McCormick equates with economic equality. Cf. McCormick 2011, 222, where in the Acknowledgements Nelson is included among those who "ruthlessly criticized the manuscript". All this clearly confirms McCormick's awareness of Guicciardini's argument against harmful effects of wealth, and his sympathies for economic equality that furthers virtue: nevertheless, the slightest allusion to it is absent in his book.

${ }^{24}$ Guicciardini is most clear that personal virtue and merit should determine a citizen's standing in Florence: “...farebbe discernere li uomini valenti dalli altri, in modo che la reputazione verrebbe facilmente in ognuno che fussi virtuoso, non fondata come molte volte oggi solo in sulla nobilità della casa ed in sul mantello del padre e de' passati, ma in sul vedersi chiare le opere e virtù, in modo che uno eccellente nato di uno padre oscuro non sarebbe mediocre, ed uno mediocre nato di uno padre e casa chiara non sarebbe sommo" (1932c, 250). As Varotti aptly comments $(1994,304)$, this is "un sistema rigorosamente meritocratico".

25 "...di volere uno giorno ridurre quella republica in questo o qualche simile modo di buona instituzione e buono governo, el quale per vedere e perchè fussi a' tempi nostri, io sanza alcuno reservo vi metterei e le facultà e la vita." There is absolutely no reason not to believe Guicciardini's sincerity here: Guicciardini is famously disinclined towards having his writings published (which is also a major reason why so much of his oeuvre was
} 
If the introduction of a radical regime, emulating also Lycurgus' extreme measures, were feasible in Florence, and such a commonwealth would be able to survive, we should not doubt Guicciardini's commitment to it - pace his own ottimato background. Note the simultaneous approval of the Spartan economic egalitarianism and, in particular, of frugal life: as he remarks in La Decima scalata, "who ordered that Republic had another object, and wanted to accustom it to arms and to poverty; so they had no other thought but to exercise themselves in arms and in virtues" $(1867 \mathrm{a}, 374) .{ }^{26}$ Commitment to renunciation of wealth and to frugal life in equalising conditions is instrumental to advancement of such high virtue. Guicciardini is, however, very clear about the uniqueness of the revered ancient polity: "amongst many Cities and Republics that existed in many centuries, there was perhaps never any other to take this route" $(374-375) .{ }^{27}$

\section{Taxing the rich and equality of "discomfort"}

Men can be poor, and yet virtuous: Guicciardini clearly believes in this proposition, including contemporary Florentine circumstances. But he is also particularly sceptical about the multitude, il populo, its ability to deliberate, and its intentions. The attitude is very noticeable already in the Discorso di Logrogno, including his short discussion about public finances. Reflecting upon how it should be decided about the tax burdens and provision of money [le gravezze e provisione di danari] for the public purse, Guicciardini asserts:

One should add that when the people has to deliberate, one falls into ut plurimum in unjust and pernicious ways which burden a lot and collect little; and being in the council many more of the poor than the rich, they do not distribute it proportionately, but want that the rich pay everything and they do not feel it, what is unjust and harmful, because it is good that the rich have to help the city, it is convenient to conserve them,

first published only in 1857-1867): cf. his remarks in Guicciardini 1932a, 5 (and Sasso's comment, 1984, 47), and Guicciardini $1867 \mathrm{~b}, 382$.

26 “...chi ordinò quella Repubblica ebbe un altro obietto, e volle avvezzarla in sulle armi e in sulla povertà; acciocchè non avessino altro pensiero che di esercitarsi nelle armi e nelle virtù."

27 “....intra tante Città e Repubbliche che sono state in tanti secoli, non ne fu mai forse nessun' altra che pigliassi questa via." 
because they make it honour and ornament, and so that they are able to help it again another time. $(1932 \mathrm{c}, 231)^{28}$

But while the judgement of the many would be certainly unjust and inefficient, that of the few may be also problematic. "If everyone has to pay according to the deliberation and thought of the few, it could generate some disorder and division, and also [these] ways could produce disturbances if they were dishonest and burdened the poor more than the rich" (232). ${ }^{29}$ Guicciardini therefore suggests to employ some sort of intermediate council, consisting of more than two hundred, perhaps three hundred, citizens: this number would mean that almost all Florentine houses are represented, and yet the body would have more prudent men, "who could be persuaded with reasons" (232)..$^{30}$

Guicciardini's proposed constitutional reform is evidently very concerned about the practical issues, and the feasibility, in the prevailing Florentine circumstances. Note how Guicciardini provides two types of arguments about overtaxing the rich: it is both "unjust and harmful", though the latter, practical side, receives much more emphasis. In his Storie fiorentine, written in the same period, where Guicciardini provides the historical account of the introduction of la decima scalata in Florence, ${ }^{31}$ he similarly offers both types of argument - about the (un)fairness and about practical negative consequences for the city (1931, XIX, 193-195). The tax is described as "an unjust and dishonest burden" which will be "of the greatest harm" to those rich in possessions (194). ${ }^{32}$ It was proposed, Guicciardini tells his

\footnotetext{
28 "Aggiugnesi che quando el populo li ha a deliberare, si getta ut plurimum a modi ingiusti e perniziosi che gravono molto e riscuotono poco; ed essendo in consiglio assai più e' poveri che e' ricchi, non le distribuiscono proporzionabilmente, ma vorrebbono che e' ricchi pagassino tutto e loro non sentirne, il che è ingiusto e dannoso, perchè se bene e' ricchi hanno a aiutare la città, è conveniente conservarli, perchè li fanno onore ed ornamento, ed acciò che e' possino aiutarla ancora in uno altro tempo."

29 '....che lo avere tutti a pagare secondo le deliberazione e pensieri de' pochi potrebbe generare qualche disordine e disparere, ed anche e' modi darebbono alterazione se fussino disonesti e gravassino più e' poveri che e' ricchi."

30 “....perchè vi sarebbe più uomini prudenti e da lasciarsi persuadere colle ragione ...perchè di tutte le case vi sarebbe quasi qualcuno, e pochi sariano quelli che non vi intervenissi alcuno de' sua."

${ }^{31}$ For a brief English summary, based on Guicciardini's account, see Najemy 2006, 402.

32 "...una gravezza ingiusta e disonesta ed in grandissimo danno di coloro che avevano entrata di possessione." In contrast, all those "rich in money", similarly to all the poor, favoured the tax: "tutti coloro che erano ricchi di danari la favorivano" (194).
} 
reader, "although it was most unjust and of harm to public, because it is the utility of the city to maintain the riches" (194). ${ }^{33}$

The question of fairness of distributing the tax burdens between the rich and the poor, only raised in the Discorso di Logrogno and in Storie fiorentine, is at the centre of La Decima scalata. The treatise, with its two discourses pro and contra the proposed tax, anticipates all the main arguments for and against progressive taxation. Guicciardini offers extremely nuanced argumentation for both positions. I analysed the arguments in detail in my recent article (Regent 2014), and I do not want to repeat them here. Nevertheless, there are some important points in the treatise, with implications for understanding equality, which deserve further attention. What I have particularly in mind is the raised question about taxing the rich. While in the Discorso di Logrogno Guicciardini offers a practical argument for taxing the rich moderately (akin to a principle used by the Masai when they blood-let their cows: they should be left in good health, so that it can be done again), in La Decima scalata the same issue is discussed in the terms of fairness. We are particularly interested in the concept of equality of "discomfort".

The speech which Guicciardini composed for the first, populist speaker of La Decima scalata constructs an opponent's standpoint with a remarkable exactitude; indeed, as I previously observed, "many supporters of progressive taxation who read the first discorso can find there whole passages that they can endorse without any problem" (Regent 2014, 328). Luigi Einaudi, a strong critic, identified in a statement of the first orator "the root of the idea of tax justice" $(1938,179) .{ }^{34}$ He provided the following quotation:

That burden has to be called equal, which burdens the poor as much as it does the rich, because when a poor pays the commonwealth a tenth of his income, and a rich pays a tenth, even if the tenth of the rich provides more than that of the poor, nevertheless the poor gets much more disordered by paying his tenth than does the rich by his. However the equality of a burden does not consist in that, that everyone pays pro rata as much as

\footnotetext{
33 “...benchè fussi ingiustissimo e di danno al publico, perchè gli è utilità della città mantenere le ricchezze."

${ }^{34}$ Einaudi 1938 can be now found also in English translation: see Einaudi 2014, 81-94.
} 
does everybody else, but that the payment is such that it causes as much discomfort to one as does to all the others. (Guicciardini 1867a, 355; 1932b, 196-197) ) $^{35}$

This concept of "discomfort" [incommodo], argues Einaudi, is the same as the concept of "sacrifice" advanced by Jeremy Bentham, so significant in various justifications for modern taxation. At the root of the concept is the sacrifice which the citizen must bear in order to finance the state: "The goodness or justice of a tax is not determined by comparison of the quantities of money paid by the citizens; but by comparison of the discomfort or sacrifice or pain or distress [l'incommodo o sacrificio o pena o dolore] suffered by the citizens in consequence of the payment of the given quantities of money" $(1938,180)$. The state, Einaudi adds sarcastically, "does not collect sacrifices, but money" (180). Yet, the criterion which is used to determine the appropriate quantity of money taken from each citizen is to be decided by the discomfort it causes him. "The psychological introspection is the premise for the concrete monetary exterior" (180).

Einaudi (1938) goes on to offer a stinging attack on the concept of equality of sacrifice and the "empty arrogance" of the "utilitarian" taxation principles: the argument includes ironic observations on the need for inventing a "psychoscope" [psicoscopio] which could measure true psychological discomfort of each citizen. Guicciardini himself, however, offers an effective answer to the early proponents of the "equality of sacrifice" principle, advocated by the first speaker in his treatise. ${ }^{36}$ The mentioned speaker asserts: "The expenses which the citizens make are from three reasons: some are necessary, other are made because of comfort, other are completely superfluous" (1867a, 355). ${ }^{37}$ The distinction corresponds to

\footnotetext{
35 “....quella gravezza s'ha a chiamare eguale, che grava tanto il povero quanto il ricco, perchè quando un povero paga in comune una decima delle entrate sue, e un ricco paga una decima, ancora che la decima del ricco getti più che quella del povero, pure molto più si disordina il povero di pagare la sua decima che il ricco la sua. Però la egualità di una gravezza non consiste in questo, che ciascuno paghi per rata tanto l'uno quanto l'altro, ma che il pagamento sia di sorte che tanto s'incomodi l'uno quanto l'altro." Einaudi quoted from Guicciardini 1932b, where there are minor differences in spelling, including the key term, incommodo instead of incomodo.

${ }^{36}$ See the discussion in Ricca-Salerno 1896, 73-76, for an emphasis on il principio della eguaglianza del sagrificio in Guicciardini's treatise; cf. Regent 2014, 310-311.

37 "Le spese che fanno i cittadini sono di tre ragioni: alcune sono necessarie, altre si fanno per comodità, altre sono totalmente superflue."
} 
necessary, useful, and superfluous wants (Regent 2014, 313; cf. De Viti de Marco 1936, 173). The proponent of progressive tax develops the argument further: even with la decima scalata in force the poor is the one who is harmed the most. For even if the poor pays the smallest proportional amount, he nonetheless has to cut down his necessary expenses. Correspondingly, the man with moderate revenue sacrifices his "comfortable" expenditure, but not the necessities, while the rich suffers only in his superfluous expenses, the previous two levels of expenditure not being affected. Therefore, even the burden of the progressive tax still disproportionately weighs down the poor (1867a, 355-356).

The answer which the speaker of second discorso offers to the first one is, as a late nineteenth-century commentator rightly put it, "apt and sharp" (Ricca-Salerno 1896, 75). ${ }^{38}$ It actually anticipates the distinction between necessaries and luxuries formulated by Adam Smith two and a half centuries later, where necessaries are defined as "not only the commodities which are indispensably necessary for the support of life, but whatever the custom of the country renders it indecent for creditable people... to be without" ([1776] 1904, V.2, 354). Even an ordinary decima (i.e. a proportional tax), argues the second orator, makes the rich suffer as much as it does the poor. For, the social conditions and their different position in the society dictate different spending needs. A rich who would spend less than is expected from him would be "reprimanded by everyone, vituperated and lacerated" (Guicciardini 1867a, 370). ${ }^{39}$ Thus already a proportional tax interferes with the necessary expenditure of the rich as it does of the poor: necessary expenses are not the same for everyone, and depend on the citizen's social rank [grado] $(370-371) .{ }^{40}$ The rich need great

\footnotetext{
${ }^{38}$ Ricca-Salerno also praised the construction of the first speaker's argument, noting how the principle of equal sacrifice developed there "in a way conforms to the doctrine of Mill" $(1896,75)$.

39 "Non conviene a ognuno fare una medesima spesa ma diverse secondo le diverse condizioni e facoltà degli uomini... e nondimeno uno ricco che non facesse più che la medesima spesa, sarebbe ripreso da ognuno, sarebbe vituperato e lacerato."

40 “...dico, che tanto patisce il ricco di una decima, quanto uno povero, e così disordina a lui le spese necessarie, come a uno povero; perchè le spese necessarie non sono a ognuno le medesime, ma sono diverse secondo $i$ gradi diversi de cittadini."
} 
expenditure in order to conserve their rank; the poor, little expenses; the mediocre, moderate (371). ${ }^{41}$ Therefore, a progressive tax hurts the rich in provision of their necessaries, not of their superfluities (371). ${ }^{42}$ The appropriate social context should be taken as a norm, the second orator in fact suggests, when making such interpersonal comparisons of (dis)utility. ${ }^{43}$

\section{Explaining the prima facie contradiction}

The second discorso of La Decima scalata argues against progressive taxation in Florence: this view is plainly endorsed by Guicciardini himself. He sides with the 'proto-libertarian' position presented by the second speaker, which defends the traditional stratified society in Florence: while citizens should enjoy political and legal equality, this should not extend in any way into the economic domain. The orator's words seem to anticipate the classical nineteenth-century liberal view of the relationship between liberty and equality; as the key statement puts it: ${ }^{44}$

I confess that the equality is good in a republic, indeed it is necessary, because it is the foundation of liberty: but the equality that is sought consists in this, that no citizen may oppress another, that everyone is equally subjected to the laws and to Magistrates, and that the bean of everyone who is fit for this Council, has the same authority as any other. This is how the equality in liberties is intended, and not generally that everybody is a peer in everything. $(368)^{45}$

It is unsurprising that Hayek eagerly quoted Guicciardini's words. ${ }^{46}$ Guicciardini also makes it very clear that economic inequalities in a polity are perfectly normal and justified, and should be left unchanged, if some citizens "have more possessions than the others, either

\footnotetext{
41 “...é necessario al ricco una spesa grande per conservare il grado suo, come al povero una piccolo, e a me che ho mediocre facoltà e possessione, una mediocre."

42 "E chi gli toglie il modo di fare simili spese, lo disordina non nelle superfluità, ma nelle cose necessarie."

${ }^{43}$ Cf. here observations made in Kahneman and Varey 1991, 138, 140.

${ }^{44}$ For a more extensive discussion, see Regent 2014, 319ff.

45 "Io confesso che la egualità è buona in una repubblica, anzi è necessaria, perchè è il fondamento della libertà: ma la egualità che si ricerca consiste in questo, che nessuno cittadino possa opprimere l'altro, che ognuno sia egualmente sottoposto alle leggi e a'Magistrati, e che la fava di ognuno che è abile a questo Consiglio abbia tanta autorità 1'una quanto l'altra. Così si intende la egualità nelle libertà, e non generalmente che ognuno sia pari in ogni cosa."

${ }^{46}$ On Hayek and Guicciardini, and Hayek's somewhat simplistic view of Guicciardini's ideas, see Regent 2014, 319-320, 326, 328.
} 
from their industry or from their predecessors or because of good fortune". This is "the universal custom of the world", and if somebody would like to take these possessions away, by the laws or by the taxes, "he would overturn the order of the world and make an injustice and iniquity convenient to robbers and assassins" (369). ${ }^{47}$ Those who amassed their possessions "justly and with reasonable methods" $(374)^{48}$ should be left to enjoy them in peace.

There is no doubt about Guicciardini's conviction about these views; this is nicely confirmed in the Dialogo del reggimento di Firenze, where Bernardo del Nero retorts to his interlocutors: "nonetheless, I say that this equality is not intended in everything; for instance that possessions of everybody are the same, for they diminish or grow according to the industry and fortune of men" (1932a, 41-42). ${ }^{49}$ And, as Bernardo continues, the important aspect of equality is "that everybody is equally under the laws, that one may not be oppressed by another; and that this parity and security can be enjoyed well, and perhaps better, under another Government when it is well ordered, as under the free Government; and for this only it is unnecessary to desire liberty" $(42) .{ }^{50}$ In other words, to protect equality under the law as well as the general security (which guarantees property rights), a "free government", i.e. a republic, is unnecessary: basic "negative" liberties can be equally (or even better) enjoyed in a well-ordered principality. ${ }^{51}$

\footnotetext{
47 “....uno o più cittadini hanno più possessioni che gl'altri, o per industria loro o de loro passati o per buona fortuna, questo è provvisto dalle leggi e dalla consuetudine universale del mondo... le quali chi volesse tôrre loro con le leggi o con le gravezze, sovvertirebbe l'ordine del mondo e farebbe una ingiustizia e una iniquità conveniente a corsali e assassini."

48 “....giustamente e co' modi ragionevoli”.

49 “....nondimeno io dico che questa equalità non s'intende in ogni cosa; verbigrazia che le sustanzie di ciascuno siano pari, perchè le vanno diminuendo o crescendo secondo la industria e fortuna degli uomini."

50 “...cioè che ognuno sia equalmente sotto le leggi, nè possa l'uno essere oppresso da l'altro; e questa parità e sicurtà s'ha tanto, e forse meglio, sotto un altro Governo quando è bene ordinato, come sotto il Governo libero; e però per questo solo non è necessario desiderare la libertà."

${ }^{51}$ Undoubtedly, a typical nineteenth-century liberal would agree that a constitutional monarchy can protect these liberties as well as a republic can (or even better). It is more interesting that Machiavelli would here fully agree with Guicciardini's analysis: see Discorsi, I.16, on "la libertà per vivere sicuri" and "la sicurtà universale", as well as his remarks in III.5, esp. on the good-governed principalities which guarantee security: "Perchè gli uomini, quando sono governati bene, non cercono nè vogliono altra libertà."
} 
Guicciardini's defence of accumulated property, and the rights of the better-off citizens against expropriation, may at first seem not particularly consistent with his arguments against the dangerous effects of excessive wealth, advanced in the Discorso di Logrogno. As we mentioned before, Guicciardini proposed such reforms in Florence, which would limit luxuries and any sumptuous display of riches: "an institution of republic where it is designed to remove inducement to riches" $(1932 \mathrm{c}, 258-259) .{ }^{52}$ Indeed, as he points out, the brash, conspicuous show of excessive wealth may harm the old (but apparently impoverished) families, as it undermines "the equality of parentadi and nobility of blood" (259). ${ }^{53}$ Guicciardini is similarly keen to advocate sumptuary laws in La Decima scalata, simultaneously as he strongly rejects taking away citizens' accumulated riches, by excessive taxation or any sort of expropriation:

....and if the superfluous expenses are harmful to the one who spends too much and as the example to others, as it is the truth, it should not be thought because of this [reason] to take away one's [property] who owns it justly; but, as the other cities do, to try to restrain the excessive expenses with the laws and with the good orders. $(1867 \mathrm{a}, 373)^{54}$

The second speaker in La Decima scalata defends the given Florentine stratified society that preserves men in their rank and possessions against a redistributive populist regime proposed by the first. There is no inconsistency if the second orator, Guicciardini's mouthpiece, reveres Lacedaemon while he simultaneously shows a strong preference for a conservative regime in Florence over populist egalitarianism, in case a Lycurgian republic is out of reach. ${ }^{55}$ For, a populist redistribution outlined by the first orator seeks to promote a better life for the multitude and equality as a goal per se, rather than being an instrument in the pursuit of virtue. Besides, as Guicciardini explains in one of the Ricordi, in corrupt

52 “....una instituzione di republica dove si disegni tôrre fomento alle ricchezze." (Quoted also in n. 21 supra.)

53 “....perchè non si conserva la equalità de' parentadi e nobilità de' sangui."

54 “....e se le spese superflue sono nocive e a chi spende troppo e per lo esempio degli altri, come è la verità, non s' ha per questo a pensare di tôrre il suo a chi lo possiede giustamente; ma, come fanno le altre città, cercare di raffinare le troppe spese con le leggi e cogli ordini buoni." (Guicciardini 1932b, 212 has raffrenare, a preferable reading adopted in the above translation.)

${ }^{55}$ Nuccio, who is more interested in the question of practical feasibility than in virtue, nevertheless reaches a conclusion which is line with our argument: "Insomma, dice Guicciardini, o la riforma è radicale, come fu quella spartana, o è destinata a fallire ed a sconvolgere l'ordine economico esistente" $(1984,932)$. 
modern circumstances wealth is actually an almost necessary requirement for the one who aims for greatness and virtue:

The appetite for goods would arise from a low or poorly composed soul, if they are desired for no other [reason] but to enjoy them; but the life in the world being corrupt as it is, for one who desires reputation it is necessary to desire goods; because with them the virtues shine and are appreciated, which in a poor man are little esteemed, and not even recognised." (1933, I.141; 1857, CCCLXIII) $)^{56}$

Moreover, as Guicciardini puts it in another ricordo, "nowadays" virtuous men are compelled to seek wealth - not an immoderate quantity, but to an adequate amount, enough "to have or conserve the reputation and authority" (1933, I.18; 1857, CCXL).${ }^{57}$ Complaining how difficult it is to stop subordinates from stealing, Guicciardini observes with displeasure that the reason for it is "that money serves for everything, and in today's life a rich [man] is more esteemed than a good [one]" (1933, II.204; 1857, CCIV). ${ }^{58}$ In his private life, Guicciardini seems to have been strongly opposed to extravagant, excessive spending. Another ricordo is very clear: "In matters of economics, the main rule is to cut off all the superfluous expenses" (1933, I.162; 1857, CCCLXXXIV). ${ }^{59}$ Guicciardini's understanding of superfluous is here in line with what his second speaker in La Decima scalata is made to argue in that treatise: "My father used to say, that one ducat which one has in purse does him more honour, than ten which one has spent; a word to be noted well, not to become stingy, nor to be lacking in honourable and reasonable things, but because it is one's brake to escape superfluous expenses" (1933, I.164; 1857, CCCLXXXVI.). ${ }^{60}$ What is "honourable and reasonable" is plainly regarded as a necessary expense - for the advancement of one's public

\footnotetext{
56 "Lo appetito della roba nascerebbe da animo basso o male composto, se non si desiderassi per altro che per poterla godere; ma essendo corrotto el vivere del mondo come è, chi desidera riputazione è necessitato a desiderare roba; perchè con essa rilucono le virtù e sono in prezzo, le quali in uno povero sono poco stimate, e manco cognosciute."

57 "È da desiderare più l'onore e la riputazione che le ricchezze; ma perchè oggidì sanza quelle male si ha e conserva la riputazione, debbono gli uomini virtuosi cercare non d'averne immoderatamente, ma tante che basti allo effetto di avere o conservare la riputazione e autorità."

58 "Ėnne cagione che el danaio serve a ogni cosa, e che al vivere d'oggi è stimato più uno ricco che uno buono."

59 "Nelle cose della economica el verbo principale è resecare tutte le spese superflue."

60 "Diceva mio padre, che più onore ti fa uno ducato che tu hai in borsa, che dieci che n'hai spesi; parola molto da notare, non per diventare sordido, nè per mancare nelle cose onorevole e ragionevole, ma perchè ti sia freno a fuggire le spese superflue."
} 
stature (and, by extension, ability to be able to exercise one's own virtue) - anything above it is superfluous and disapproved..$^{61}$

An ottimato, a patrician from one of the best Florentine families, Guicciardini strongly opposes an intrusive progressive tax. If the Spartan solution is unavailable to a commonwealth, Guicciardini then prefers no redistribution whatsoever: in a corrupt world, wealth is a protection for a prominent man, who can try to pursue virtue on the individual level. All the other, redistributive solutions in a commonwealth, which may be seen as being "in between" the two extremes - a radical Lycurgian republic modelled on Sparta, and the given stratified society (such as Florence without la decima scalata) - are worse options. When I recently reconstructed and explained Guicciardini's position, I emphasised the significant implications which follow for the nowadays usual understanding of political preferences, with the unimodal distribution, along the left-right (or another similar) continuum (Regent 2014, 325-326, cf. 328-329). What seems also rather unusual today, is the instrumental understanding of equality. Rather than promoting equality - and the connected better economic conditions for the large mass of polity's population - as an ideal worthy in itself, the ancient ideal which inspired Guicciardini saw virtue as the leading goal. Unlike more modern and contemporary egalitarian theories, the older view, often associated with the republican tradition, saw equality as an instrument for a higher aim; that equality was moreover simultaneous with frugality. ${ }^{62}$ In contrast, there is hardly any contemporary egalitarian who is not interested in increasing the wealth of the population and eliminating

\footnotetext{
${ }^{61}$ The important method, Guicciardini emphasises, is to know "how to spend with advantage", this is the main factor in "the prudence of economics"; it is more important than to know how to "guard oneself" in making expenses, for these are "many times necessary": "Non consiste tanto la prudenzia della economica in sapersi guardare dalle spese, perchè sono molte volte necessarie, quanto in sapere spendere con vantaggio, cioè uno grosso per 24 quattrini" (1933, II.56; 1857, LVI). Cf. also the continuation of the above-quoted 1933, I.162 / 1857, CCCLXXXIV: “...ma quello in che mi pare consista la industria è el fare le medesime spese con più vantaggio che non fanno gli altri; e, come si dice vulgarmente, spendere el quattrino per cinque denari."

${ }^{62}$ For a classic statement of the connection between equality and frugality in the republican tradition, see Montesquieu [1748] 1989, V.4, cf. also V.3.
} 
poverty (usually with an ever increasing lower threshold ${ }^{63}$ ), rather than advocating an austere, frugal life with few necessities. The seriousness with which the contemporary egalitarian theorists discuss the question of so-called "expensive tastes" shows well how far they are from any ancient ideal of economic equality. ${ }^{64}$

\section{Concluding observations}

The ancient ideal of an egalitarian commonwealth - revived by a number of early-modern writers - was very much dedicated to virtue in arms. Advancement of population's material conditions, and the associated effect of growing availability of luxuries, can actively harm such an aim: it makes men effeminate, unsuitable for arms; it helps maintaining, as Guicciardini put it, the "softness of our souls". Equality of economic conditions, when introduced, must be associated with frugality and austere, limited means. Lycurgus' constitution in Sparta, admired by Guicciardini, through its dedication to a life of austere virtue, managed to guarantee such conditions for a very long time. Indeed, the longevity of Sparta and her life in liberty (i.e. as an independent republic) was a feature particularly cherished in the republican tradition. ${ }^{65}$ Lack of interest in Guicciardini's writings is clearly a major explanandum why the importance of this influence was unnoticed until recently. ${ }^{66}$ However, the complexity of Guicciardini's ideas can mislead a commentator: many of his works are still underexplored, and, sometimes, almost completely unknown; moreover, what is written on him, is often misleading.

\footnotetext{
${ }^{63}$ There might be some problems here, equality being sometimes in collision with the best achievable economic growth: see e.g. G.A. Cohen's arguments (2008, esp. ch. 2) against Rawls.

${ }^{64}$ See e.g. Cohen 2011, which gives a good idea about the debate between him and Ronald Dworkin.

${ }^{65}$ In the Discorsi, Machiavelli opts for Rome over Sparta when discussing republican constitutions, despite recognising the latter's double longevity: in Regent 2011, 757-763, I trace the roots of his choice to Polybius, and give an idea of the appreciation of the qualities of the Lacedaemonian constitution in "maintaining" freedom. McCormick 2011, 54, suggests that the Spartan regime "is not a republic at all, but rather a principality": an utterly amazing statement to anybody acquainted with the republican tradition (cf. here Guicciardini's remarks, 1932a, 105).

${ }^{66}$ As representative, see e.g. Rawson 1969, 143-144 (cf. Regent 2008, 12).
} 
The already mentioned recent study (McCormick 2011), apparently influential, seriously misrepresents Guicciardini's views on wealth and organisation of the body politic, portraying him as an apologist for the rich citizens' "oligarchy" ${ }^{67}$ While one has to be careful with such characterisations even when concerning Guicciardini's later works, ${ }^{68}$ to present the argument of the Discorso di Logrogno as advancing the cause of wealthy "oligarchs" is to purposely mislead one's own reader. ${ }^{69}$ In a well-ordered Florentine republic proposed in this work, Guicciardini is explicit, an "excellent" son born of an "obscure" father would not be regarded a "mediocre", nor would be a "mediocre" son born of an "illustrious father and house" regarded as outstanding $(1932 \mathrm{c}, 250) .{ }^{70}$ Virtue and "good deeds" would be rewarded, while incompetence and malice would be "neglected and dishonoured" (250). ${ }^{71}$ By rewarding

\footnotetext{
${ }^{67}$ Readers should note that McCormick 2011 uses both Machiavelli and Guicciardini as pawns to advance a certain contemporary political agenda; the book is an exceedingly biased attempt marred by poor scholarship which disregards and/or misinterprets facts which do not support the author's grand thesis. In his final chapter [7] McCormick "propose[s] a hypothetical elite-accountability institution to be amended to the U.S. Constitution"; his interpretation of Machiavelli the "democrat" serves to this very purpose. And, as he admits, "I will consistently use Guicciardini as an oligarchically inclined foil for Machiavelli throughout this book" (n. 26 at 195). While he adds in the next sentence how "[he] completely agree[s] with Pocock's injunction against crudely reading the former as merely a 'mouthpiece' for his class", McCormick's judgement reiterated throughout the book is: "as mentioned before, Guicciardini crystallized the aspirations of wealthy and notable citizens within republics and served as a crucial if unrecognized conduit between the republicanisms of Cicero and James Madison" (144). [Note that second part of McCormick's claim is completely impossible (cf. an equivalent claim, n. 39 at 207): as I had emphasised three years before McCormick 2011 was published, about a similar mistake in Pocock (Regent 2008, 2), Guicciardini's political works were made known to the public only from 1857 onwards, and Madison was not even aware of their existence.]

${ }^{68}$ See e.g. Guicciardini 1932a, 106, where, praising the Venetian system, Bernardo del Nero observes "perchè si chiama Governo di gentiluomini ed il nostro [i.e. fiorentino] si chiamerà di popolo, non per questo è di spezie diversa, perchè non è altro che uno Governo nel quale intervengono universalmente tutti quegli che sono abili agli uffici, ne vi si fa distinzione o per ricchezza o per stiatte, come si fa quando governano gli ottimati, ma sono ammessi equalmente tutti a ogni cosa, e di numero sono molti e forse più che siano i nostri". This is noted in Pocock 1975, 258, who comments: "In each system... the ruling elite emerge solely through the display of the necessary qualities and the recognition and choice of their fellows." Of course, the franchise is similarly limited both in Venice and in Florence, for, as Guicciardini continues: “...e se la plebe non vi participa, la non participa anche a noi, perchè infiniti artefici, abitatori nuovi ed altri simili, non entrano nel nostro consiglio".

${ }^{69}$ McCormick quotes Discorso di Logrogno 22 times - it is Guicciardini's work he quotes most often (followed by Storie fiorentine (15x) and Dialogo del reggimento di Firenze (7x)). McCormick's claims about the Discorso include "that Guicciardini likely expects the most wealthy or notable individuals to have an advantage" (110) and "tend to elevate the most virtuous, prudent, just (read: wealthy and prominent) citizens to office" (108). McCormick pretends that Guicciardini's argument against wealth does not exist: yet he quotes twice $(123, \mathrm{n}$. 18; 124, n. 25) from p. 147 in Moulakis' translation (Guicciardini 1998), where the argument against wealth starts, and where at the bottom of the page one reads: "It would be necessary to abolish the great value and prestige attributed to wealth..." The whole argument against wealth is in Moulakis' translation formed in a separate section entitled "Epilogue", which McCormick, quoting so often from the treatise, must have read.

${ }^{70}$ For the Italian original see supra, n. 24.

71 "Sarebbono adunche le opere buone e le virtù remunerate secondo quella misura che si può in una republica, e consequentemente negletta ed inonorata la malizia e la ignoranzia."
} 
merit, the republic should channel the ambition of its best and most capable citizens, having for them in sight the highest honour, that of becoming the head of a free city (250-251). "Happy [are] the republics which are full of this ambition", for there flourish "virtues and good deeds", and there is "an ardent appetite" to achieve "great and generous deeds for the benefit of the fatherland" in the men who strive for such prominence $(251){ }^{72}$

Wealth, however, with its corrupting effect, has an adverse impact on the citizens' pursuit of virtue. ${ }^{73}$ Worried about pernicious effects of wealth, Guicciardini (in his younger years) apparently thought that introducing economic equality in a commonwealth could be a worthwhile aim, but only because it is an excellent instrument for achieving virtue. Excessive wealth and luxury are harmful for any city, and the preoccupation with gaining wealth "alienates the souls from seeking virtue". Yet, in an imperfect world, where political conditions make it unfeasible - or, indeed, impossible - to thoroughly reform the commonwealth, and turn it into a Lycurgian republic, wealth, paradoxically, can give a degree of independence to an outstanding man, to be able to seek virtue individually.

\section{Funding}

Research for this article was funded by the Australian Research Council grant DE140101358. The first version of the article was written for, and presented at, the 20th European Society for the History of Economic Thought (ESHET) annual conference on Inequalities in Economic Thought at the Université Paris 1 Panthéon-Sorbonne (26-28 May 2016).

\section{References}

Cohen, G.A. 2008. Rescuing Justice and Equality. Cambridge: Harvard University Press.

Cohen, G.A. 2011. "Expensive Taste Rides Again." In On the Currency of Egalitarian Justice, and Other Essays in Political Philosophy. Edited by Michael Otsuka. Princeton University Press, 81-115.

\footnotetext{
72 “...felice le republiche che sono piene di questa ambizione, perchè li è necessario che vi fiorischino... le virtù ed opere buone, sievi uno appetito ardente di fare opere grande e generose a beneficio della patria ed in coloro che desiderano venire in questa autorità, ed in quelli che già vi sono."

73 The described ambition in service of his patria is something which Guicciardini evidently cherished personally. "Happy are the souls of those", he wrote, "who feel this flame": "Felici sono li animi di coloro che sentono questa fiamma" (1932c, 251).
} 
De Viti de Marco, Antonio. 1936. First Principles of Public Finance. Translated by Edith Pavlo Marget. London: Jonathan Cape.

Einaudi, Luigi. 1938. "La vuota boria dei sommi principi utilitari dell'imposta." In Miti e paradossi della giustizia tributaria. Torino: Giulio Einaudi, 179-200.

Einaudi, Luigi. 2014. Selected Economic Essays, Volume 2. Edited by Riccardo Faucci and Roberto Marchionatti. Basingstoke: Palgrave Macmillan.

Green, Jeffrey Edward. 2011. "Learning How Not to Be Good: A Plebeian Perspective." The Good Society 20 (2): 184-202.

Green, Jeffrey Edward. 2016a. "Liberalism and the Problem of Plutocracy." Constellations 23 (1): 84-95.

Green, Jeffrey Edward. 2016b. The Shadow of Unfairness: A Plebeian Theory of Liberal Democracy. Oxford: Oxford University Press.

Guicciardini, Francesco. 1857. Ricordi politici e civili. In Opere inedite, vol. 1. Edited by Giuseppe Canestrini. Firenze: Barbèra, Bianchi e comp., 81-224.

Guicciardini, Francesco. 1858. Del modo di mantenere il Governo popolare col Consiglio Grande, dopo che fu deciso nella Dieta di Mantova, dagli Imperiali, dagli Spagnuoli e dal papa, di rimettere i Medici in Firenze [Discorso di Logrogno]. In Opere inedite, vol. 2. Edited by Giuseppe Canestrini. Firenze: Barbèra, Biahchi e comp., 262-315.

Guicciardini, Francesco. 1864. Relazione di Spagna. In Opere inedite, vol. 6. Edited by Giuseppe Canestrini. Firenze: M. Cellini e comp., 271-297.

Guicciardini, Francesco. 1867a. La Decima scalata. In Opere inedite, vol. 10. Edited by Giuseppe Canestrini. Firenze: M. Cellini e comp., 353-378.

Guicciardini, Francesco. 1867b. Del suicidio per ragione di libertà o di servitù. In Opere inedite, vol. 10. Edited by Giuseppe Canestrini. Firenze: M. Cellini e comp., 382-388.

Guicciardini, Francesco. 1929. Storia d'Italia. 5 vols. Edited by Constantino Panigada. Bari: Laterza.

Guicciardini, Francesco. 1931. Storie fiorentine dal 1378 al 1509. Edited by Roberto Palmarocchi. Bari: Laterza.

Guicciardini, Francesco. 1932a. Dialogo del reggimento di Firenze. In Dialogo e discorsi del reggimento di Firenze. Edited by Roberto Palmarocchi. Bari: Laterza, 1-172.

Guicciardini, Francesco. 1932b. La decima scalata. In Dialogo e discorsi del reggimento di Firenze. Edited by Roberto Palmarocchi. Bari: Laterza, 196-217.

Guicciardini, Francesco. 1932c. Del modo di ordinare il governo popolare [Discorso di Logrogno]. In Dialogo e discorsi del reggimento di Firenze. Edited by Roberto Palmarocchi. Bari: Laterza, 218-59.

Guicciardini, Francesco. 1933. Ricordi. In Scritti politici e Ricordi. Edited by Roberto Palmarocchi. Bari: Laterza, 239-335.

Guicciardini, Francesco. 1986. Le lettere. Vol. 1. Edited by Pierre Jodogne. Roma: Istituto Storico Italiano per l'età Moderna e Contemporanea.

Guicciardini, Francesco. 1991. Ricordanze. In Ricordi, diari, memorie. Pordenone: Edizioni Studio Tesi, 71-129.

Guicciardini, Francesco. 1998. Discorso di Logrogno (On How to Order a Popular Government). In Republican Realism in Renaissance Florence: Francesco Guicciardini's Discorso di Logrogno. Edited by Athanasios Moulakis. Lanham: Rowman \& Littlefield, 117-149. 
Kahneman, Daniel, and Varey, Carol. 1991. "Notes on the Psychology of Utility." In Interpersonal Comparisons of Well-Being. Edited by Jon Elster and John E. Roemer. Cambridge: Cambridge University Press, 127-163.

Machiavelli, Niccolò. [c. 1513-19] 1971. Discorsi sopra la prima deca di Tito Livio. In Tutte le opere. Edited by Mario Martelli. Firenze: Sansoni, 73-254.

McCormick, John P. 2011. Machiavellian Democracy. Cambridge: Cambridge University Press.

Montesquieu, Charles de Secondat. [1748] 1989. The Spirit of the Laws. Translated by Anne M. Colher, Basia C. Miller and Harold S. Stone. Cambridge: Cambridge University Press.

Najemy, John M. 2006. A History of Florence 1200-1575. Oxford: Blackwell.

Nelson, Eric. 2004. The Greek Tradition in Republican Thought. Cambridge: Cambridge University Press.

Nuccio, Oscar. 1984. "Francesco Guicciardini: finanza pubblica ed ordine sociale." In Il pensiero economico italiano. Vol. 1. Sassari: Gallizzi, 893-938.

Palmarocchi, Roberto. 1939. "L'ambasceria del Guicciardini in Spagna."Archivio storico italiano 97 (2): 145-169.

Pocock, J.G.A. 1975. The Machiavellian Moment: Florentine Political Thought and the Atlantic Republican Tradition. Princeton: Princeton University Press.

Rawson, Elizabeth. 1969. The Spartan Tradition in European Thought. Oxford: Clarendon Press.

Regent, Nikola. 2008. “A 'Medical Moment': Guicciardini and Lycurgus' Knife.” History of European Ideas 34 (1): 1-13.

Regent, Nikola. 2011. "Machiavelli: Empire, Virtù and the Final Downfall." History of Political Thought 32 (5): 751-772.

Regent, Nikola. 2014. "Guicciardini's La Decima scalata: the First Treatise on Progressive Taxation.” History of Political Economy 46 (2): 307-331.

Regent, Nikola. 2019. "In the Shadow of Lacedaemon: Luxury, Wealth and Early-Modern Republican Thought." Journal of the History of Economic Thought 41 (4): 477-509.

Ricca-Salerno, Giuseppe. 1896. Storia delle dottrine finanziarie in Italia. 2nd edition. Palermo: Alberto Reber.

Ridolfi, Roberto. 1967. The Life of Francesco Guicciardini. London: Routledge and Kegan Paul.

Sasso, Gennaro. 1984. "Guicciardini e Machiavelli." In Per Francesco Guicciardini. Roma: Istituto Storico Italiano per il Medio Evo, 47-158.

Smith, Adam. [1776] 1904. An Inquiry into the Nature and Causes of the Wealth of Nations. Edited by Edwin Cannan. London: Methuen \& Co.

Varotti, Carlo. 1994. "Patriziato e nobiltà nel Dialogo del reggimento di Firenze di Francesco Guicciardini." Il pensiero politico 27 (2): 303-313.

Acknowledgment:

The Version of Record of this manuscript has been published and is available in European Journal of the History of Economic Thought (published online: 16 Dec 2019) at http://www.tandfonline.com/ doi.org/10.1080/09672567.2019.1651360 